\title{
PENGENALAN BAHASA DAERAH MARORI MENGGUNAKAN TEKNIK RETRIVAL JARINGAN SEMANTIK
}

\section{INTRODUCTION OF MARORI REGIONAL LANGUAGE USING SEMANTIC NETWORK RETRIVAL TECHNIQUES}

\author{
Tobias Nggaruaka $^{1}$, Agus Kichi Hermansyah ${ }^{2 a}$, Ranta Butarbutar ${ }^{3}$ \\ ${ }^{1}$ Pendidikan Bahasa dan Sastra Indonesia, Fakultas Keguruan dan Ilmu Pendidikan, Universitas Musamus, Jl \\ Kamizaun Mopah Lama Merauke, Indonesia \\ ${ }^{2}$ Pendidikan Guru Sekolah Dasar, Fakultas Keguruan dan Ilmu Pendidikan, Universitas Musamus, Jl \\ Kamizaun Mopah Lama Merauke, Indonesia \\ ${ }^{3}$ Pendidikan Bahasa Inggris, Fakultas Keguruan dan Ilmu Pendidikan, Universitas Musamus, J1 Kamizaun \\ Mopah Lama Merauke, Indonesia \\ aKorespondensi: Agus Kichi Hermansyah, E-mail: aguskichi@unmus.ac.id
}

\begin{abstract}
The purpose of this study was to introduce regional language (Marori) vocabulary as a mother tongue to SD Negeri Wasur 1 Merauke students. In addition, another research objective that can be achieved in this research is to develop students' loving for mother tongue (Marori) which fades from day to day. The learning method used in this study is a semantic network retrival technique that is by linking the concept of vocabulary to students' lives. Learning is associated with student schemata with MaindMaple Lite media. This research method is a qualitative research with case study research type. The emphasis in this research is on the aspect of in-depth understanding to see problems in a problem. With the existence of qualitative research can produce meaning and information in accordance with the research objectives. Data obtained in this study were analyzed inductively. The results showed that there was an increase in the vocabulary of regional languages (Marori). The first meeting as many as 8 students were able to metrify 6 words with $100 \%, 6$ students retreated 4 words $(22.22 \%), 4$ students retreated 4 words $(22.22 \%)$. In the second meeting 10 students retreated 6 words (100\%), 6 students retreated 5 words $(22.22 \%)$, and 2 students retreated 4 words $(22.22 \%)$. The third meeting consisted of 12 students with 8 words (100\%), 2 students with 7 words $(11.11 \%)$ and 4 students with 7 words $(22,22 \%)$. The fourth meeting of 18 students was able to retract 11 words with a semantic map design with $100 \%$ presentation.
\end{abstract}

Keywords: learning; vocabulary; retrival technique; semantic network.

\begin{abstract}
ABSTRAK
Tujuan penelitian ini adalah mengenalkan kosakata bahasa daerah (Marori) sebagai bahasa ibu kepada siswa SD Negeri Wasur 1 Merauke. Selain itu tujuan penelitian lain yang dapat dicapai dalam penelitian ini adalah menumbuhkembangkan rasa kecintaan siswa terhadap bahasa ibu (Marori) yang dari hari ke hari semakin pudar. Metode pembelajaran yang digunakan dalam pembelajaran ini adalah teknik retrival jaringan semantik yakni dengan mengaitkan konsep kosakata dalam kehidupan siswa. Pembelajaran dikaitkan dengan skemata siswa dengan media MaindMaple Lite. Metode penelitian ini adalah penelitian kualitatif dengan jenis penelitian studi kasus. Penekanan dalam penelitian ini adalah pada aspek pemahaman secara mendalam untuk melihat permasalahan dalam suatu masalah. Dengan adanya penelitian kualitatif dapat menghasilkan makna dan informasi yang sesuai dengan tujuan penelitian. Data yang diperoleh dalam penelitian ini dianalisis secara induktif. Hasil penelitian menunjukkan bahwa terdapat peningkatan perbendaharaan kosakata bahasa daerah (Marori). Pertemuan pertama sebanyak 8 siswa mampu metriv 6 kata dengan 100\%, 6 siswa meretriv 4 kata
\end{abstract}


$(22,22 \%), 4$ siswa meretrif 4 kata $(22,22 \%)$. Pertemuan kedua sebanyak 10 siswa meretrif 6 kata (100\%), 6 siswa meretrif 5 kata $(22,22 \%)$, dan 2 siswa meretrif 4 kata $(22,22 \%)$. Pertemuan ketiga sebanyak 12 siswa meretrif 8 kata (100\%), 2 siswa meretrif 7 kata $(11,11 \%)$ dan 4 siswa meretrif 7 kata $(22,22 \%)$. Pertemuan keempat dari jumlah 18 siswa mampu meretrif 11 kata dengan desain peta semantik dengan presentasi $100 \%$.

Kata kunci: pembelajaran, kosakata, teknik retrival, jaringan semantik.

Nggaruaka, T., Hermansyah, A.K., \& Butarbutar, R. (2019). Pengenalan Bahasa Daerah Marori Menggunakan Teknik Retrival Jaringan Semantik. Didaktika Tauhidi: Jurnal Pendidikan Guru Sekolah Dasar, 6(2), 93-103

\section{PENDAHULUAN}

Papua merupakan salah satu wilayah paling timur Nusantara dengan memperlihatkan kompleksitas bahasa serta multilingualisme. Ada dua rumpun bahasa yaitu bahasa nonAustronesia dan Austronesia. Kedua bahasa ini merupakan bahasa induk yang di dalamnya terdapat bahasa-bahasa lokal Papua yang tersebar di enam (6) wilayah adat yaitu di dua Provinsi yakni Papua dan Papua Barat. Karakteristik bahasa yang berbeda-beda tetapi tetap masuk dalam rumpun bahasa Austornesia. Rumpun bahasa tersebut ialah: (1) bahasa Biak, (2) bahasa Wamdamen, (3) bahasa Waropen, dan (4) bahasa Maya. Sedangkan yang tergolong bahasa NonAustronesia yaitu bahasa Meybrat, bahasa Dani, bahasa Ekari, bahasa Asmat, bahasa Muyu dan bahasa Sentani (Mansoben, 1994).

Di Papua New Guinea pada tahap pendidikan prasekolah non formal telah melakukan gerakan pendidikan dengan salah satu gerakan yang dinamakan Tok Ples Pri Skul dimulai pada akhir 1970-an. Gerakan itu kemudian sebagai salah satu terobosan pengajaran literasi dan berhitung dalam bahasa lokal. Kemudian pada 1980-an, kegiatan tersebut tampak bahwa sistem pendidikan formal berkontribusi pada aliansi pemuda bangsa. Dörthe Bühmann Barbara Trudell menyebutkan bahwa reformasi pendidikan pada tahun 1995 memberikan dampak positif dengan nama gerakan Tok Ples Pri Skul (Trudell, 2008). Hal ini memberikan beberapa implikasi yaitu: (a) populasi pendidikan semacam ini dihargai, (b) pengembangan sarana untuk membuat bahan ajar dan kurikulum dalam bahasa lokal, (c) kepedulian pihak-pihak dalam pembelajaran bahasa lokal dengan mengangkat persoalan tersebut ke tingkat nasional maupun dan tingkat provinsi, dan (d) membangun jaringan kerja sama non pemerintah (LSM) dan pemerintah pusat.

Kajian pemertahanan bahasa-bahasa lokal di Papua perlu dilakukan secara berkesinambungan, kerana bahasa merupakan salah satu aset budaya dan sebagai identitas kedaerahan yang perlu dilestarikan dari generasi ke generasi. Faktor-faktor dari kesulitan siswa dalam meretrif kosakata bahasa daerah adalah faktor lingkungan dan keluarga. Patana dan Sumarsono menyebutkan bahwa penguasaan kosakata anak dapat dipengaruhi oleh berbagai 
faktor baik lingkungan keluarga, sosial, dan lingkungan bermain anak (Sumarsono, 2002).

Salah satu kosakata yang familiar dalam kehidupan masyarakat adalah pembedaharaan Pohon sagu. Pohon sagu memiliki perbendaraan kosakata yang kaya (Hisa, 2017). Perbendaharaan kosakata merupakan salah satu aspek penting dalam berbahasa. Setiap anak dibekali dengan kemampuan bahasa, hanya saja jika tidak diajarkan maka kemampuankemampuan bahasa tersebut tidak dapat dimanfaatkan dalam proses pemerolehan bahasa. Sebagaimana dikatakan oleh (Soedjito, 1992) bahwa keseluruhan kosakata atau perbendaharaan kata yang terdapat dalam suatu Bahasa. Lebih lanjut (Tarigan, 1994) berpendapat keterampilan berbahasa seseorang meningkat apabila kuantitas dan kualitas kosakatanya meningkat dalam pembelajaran. Upaya mempertahankan bahasa daerah dari dapat dilakukan berbagai pihak. Salah satu upaya yang dilakukan adalah pengenalan kosakata bahasa daerah (Marind-Marori) di SD sebagai upaya menumbuhkembangkan kecintaan bahasa daerah sejak dini. Tentu bukan hal yang mudah untuk kemudian meningkatkan pemahaman dan kecintaan bahasa daerah, tetapi marilah bersamasama membangun salah satu paradigma bahwa dengan masuknya gerakan literasi bahasa daerah sejak dini ke sekolah akan memberikan wawasan tambahan kepada siswa. Jika dilihat materi yang diajarkan yaitu pengenalan pohon sagu dan proses pengelolahan, dan pengenalan nama marga. Marga sangat melekat bahkan anak-anak di dalam kelas rata-rata memakai nama marga. Namun, ketika dilakukan pendalaman nampaknya anak-anak kesulitan dan meretrif kembali makna marga dalam pembelajaran bahasa.

Pembelajaran bahasa merupakan proses yang mesti dilakukan secara berkesinambungan dan berbasis proses. Menurut Krashen (Ghazali, 2013) dalam proses pembelajaran bahasa kedua di kelas ada beberapa ciri-ciri pengajaran bahasa yang perlu dipenuhi yaitu: (1) dapat dipahami oleh siswa, (2) menarik bagi siswa, (3) bertaut dengan minat siswa, dan (4) tidak harus disajikan dengan memperhatikan urutan gramatikal, dan input tidak harus disajikan dengan takaran yang tidak berlebian. Lebih lanjut Ghazali, (2013) menyatakan bahwa pengajaran bahasa (kosakata) dalam kelas dapat mendorong terjadinya proses pemerolehan bahasa asalkan pengajaran dapat menyediakan input yang dapat dipahami maknanya oleh pembelajar. Dan lebih penting lagi pembelajar dapat memberikan kesempatan kepada pelajar dalam mempelajari bahasa target secara fungsional dan dalam interaksi komunikatif.

Untuk menanamkan konsep/kosakatan bahasa perlu dilakukan sejak dini Slobin pernah menemukan bahwa pemerolehan bahasa dibagun sejak dini, dan kemampuan bahasa itu dikembangkan sehiring perkembangan fisik anak dan berdasarkan pengalaman interaksi di dalam kehidupan anak (Dawud, 2008). Pembelajaran 
keterampilan bahasa (menyimak, berbicara, membaca, dan menulis) memiliki karakteristik tersendiri. Kemampuan pembelajaran ketiga menghadapi mata rantai tersebut yaitu (1) pembelajaran memiliki kemampuan untuk memberikan respon terhadap suatu rangsangan, (2) secara intuitif, pembelajaran evaluasi penghargaan yang didapat karena memberikan respon yang benar, (3) pembelajaran mampu mmeberikan parameter yang membangun mata rantai Rangsangan-Respon yang didapat karena memberikan respon positif, dan (4) pembelajaran mampu membuat generalisasi terhadap proses belajar tersebut dan mampu pula menerapkan pada situasi yang mirip, sehingga mata rantai Rangsangan-Respon-Ganjaran itu dapat dibentuk (Ghazali, 2013).

Penelitian ini bertujuan mengenalkan dan membelajarkan bahasa Marori kepada siswa dengan teknik retrival jaringan semantik. Dengan teknik retrival jaringan semantik siswa mampu memperoleh kosakata bahasa Marori dan mampu meretrif kosakata bahasa daerah (Marori). Peta semantik atau peta konsep merupakan salah satu metode pembejaran efektif. Sebagaimana Widyawati, 2017 menunjukkan bahwa pembelajaran menggunakan Maind Mapping (peta konsep) dapat berpengaruh terhadap hasil belajar kosakata bahasa Inggris. Hyerle \&Alper, 2012:3 menyatakan bahwa peta pikir (peta konsep) secara langsung mendukung penguasaan bahasa, pemahaman bacaan, proses penulisan, dan simbol matematika. Hyerle \&Alper (2012:4) mempertegas bahwa peta pikiran/peta semantik merupakan bahasa pola, dari proses kognitif sebagai salah satu cara untuk menjadi sadar akan dan mengirimkan operasi mental ke lingkungan pembelajaran apa pun.

\section{METODE}

\section{Jenis Penelitian}

Penelitian ini adalah penelitian kualitatif dengan jenis penelitian studi kasus. Menurut Sugiono menyatakan bahwa penelitian kualitatif lebih ditekankan pada aspek pemahaman secara mendalam untuk melihat permasalahan dalam suatu masalah (Sugiono, 2016). Dengan adanya penelitian kualitatif dapat menghasilkan makna dan informasi yang sesuai dengan tujuan penelitian. Proses penelitian yang dilakukan berupaya menemukan data secara ilmiah. Keilmiahaan data diperoleh berdasarkan proses pembelajaran dengan menerapkan teknik retrival jaringan semantik sebagai upaya pengenalan bahasa daerah kepada siswa.

\section{Waktu dan Tempat Penelitian}

Penelitian ini dilakukan pada bulan Juli sampai dengan September 2019. Tempat Penelitian yang digunakan adalah SD Negeri Wasur 1 yang beralamat di jalan Trans Papua, Kampung Wasur.

\section{Target/Subjek Penelitian}

Subjek penelitian dilakukan pada siswa kelas V SD Negeri Wasur 1 Merauke dalam pembelajaran Bahasa Indonesia.

\section{Prosedur Penelitian}

Data dalam penelitian ini dianalisis secara induktif. Kemudian data yang diperoleh dianalisis 
dalam bentuk deskripsi fenomena bukan perhitungan angka-angka. Hal ini sejalan dengan karakteristik penelitian kualitatif yang terdiri dari enam bentuk, yaitu (1) latar penelitian sebagai sumber pengambilan data bersifat alamiah, (2) bersifat deskripsi, (3) bersifat induktif, (4) peneliti menjadi instrumen kunci, (5) menekankan pada proses selain hasil, dan (6) makna menjadi tekanan utama (Robert C Bogdan, 1990).

\section{Data Penelitian, Instrumen, dan Teknik Pengumpulan Data}

Data penelitian yang terkumpul berupa data hasil pengamatan, hasil wawancara, hasil catatan lapangan, hasil proses pembelajaran pengenalan kosakata bahasa (Marori-Marind) dalam pembelajaran bahasa Indonesia dengan menggunakan teknik retrival jaringan semantik. Data proses pembelajaran berupa aktivitas guru dalam penggunaan teknik retrival jaringan semantik dalam pembelajaran. Sementara data siswa diperoleh berdasarkan interaksi guru dan siswa di dalam pembelajaran pengenalan kosakata bahasa (Marori-Marind).

\section{Teknik Analisis Data}

Analisis data yang digunakan dalam penelitian ini adalah model mengalir, yang dipaparkan oleh Miler dan Huberman (Miles B Huberman, 1986) yakni dimulai dari menelaah seluruh data yang terkumpul. Data yang terkumpul berupa data hasil pengamatan, hasil wawancara, hasil catatan lapangan, dan hasil proses pembelajaran kosakata dengan menggunakan teknik retrival jaringan semantik. Data proses pembelajaran berupa aktivitas guru dalam penggunaan teknik retrival jaringan semantik dalam pembelajaran kosakata bahasa Marori. Sementara data siswa diperoleh berdasarkan interaksi guru dan hasil belajar siswa di dalam pembelajaran kosakata menggunakan teknik retrival jaringan semantik. Hasil belajar siswa diperoleh mengacu pada proses dan hasil tulisan siswa yang selanjutnya dianalisis.

\section{HASIL PENELITIAN DAN PEMBAHASAN}

\section{Hasil}

Penelitian yang dilakukan di SD Negeri Wasur 1 dimulai pada kegiatan pembelajaran Bahasa Indonesia. Pembelajaran dilaksanakan sebanyak 4 kali pertemuan. Berdasarkan hasil penelitian tampak bahwa penguasaan kata siswa setiap pertemuan berbeda-beda. Setiap siswa memiliki kemampuan dalam memahami kata benda/hewan yang menjadi bahan pembelajaran dalam bahasa Indonesia tetapi ketika dirumuskan dalam pertanyaan bahasa Marori, siswa nampak kesulitan kerena bahasa Marori (Marind) menjadi salah satu bahasa daerah yang hampir punah. Keprihatinan inilah yang kemudian menjadi dasar untuk melakukan penelitian ini.

Berdasarkan hasil pengelolaan data menunjukkan bahwa pertemuan pertama dari jumlah 18 siswa 8 siswa menyebutkan/meretrif 6 kata nama benda/tumbuhan berberdasarkan makna kata bahasa Marori, dan fungsinya, serta berdasarkan pengetahuan siswa. Sementara 6 siswa mampu meretrif kata beda/hewan dan 
mampu mengembangkan peta semantik dengan presentasi 33,33\%. Sedangkan 4 siswa lainnya menyebutkan/meretrif 4 kata nama benda/tumbuhan berberdasarkan makna kata bahasa Marori, dan tidak menyebutkan fungsi kata tersebut. Deskripsi pertemuan dalam pembelajaran kosakata bahasa Marori terdapat sebanyak 10 siswa mampu menyebutkan/meretrif 6 kata nama benda/tumbuhan berdasarkan makna kata bahasa Marori dan fungsinya. Serta berdasarkan pengetahuan siswa dengan presentasi 100\%. 6 siswa menyebutkan/meretrif 5 kata nama benda/tumbuhan berberdasarkan makna kata bahasa marori dengan presentasi $22,22 \%$, dan 2 siswa menyebutkan/meretrif 4 kata nama benda/tumbuhan berdasarkan makna kata bahasa marori, dan tidak menyebutkan fungsi kata tersebut dengan presentasi 22,22\%.

Pada Pertemuan ketiga terdapat sebanyak 12 siswa mampu menyebutkan/meretrif 8 kata nama benda/hewan berberdasarkan makna kata bahasa Marori, dan fungsinya, serta berdasarkan pengetahuan dengan presentasi 100\%, 2 siswa menyebutkan/meretrif 7 kata nama benda/tumbuhan berberdasarkan makna kata bahasa Marori dengan presentasi 11,11\%, dan 4 siswa menyebutkan/meretrif 6 kata nama benda/hewan berberdasarkan makna kata bahasa Marori, dan tidan menyebutkan fungsi kata tersebut dengan presentasi $22,22 \%$. Pada proses pengenalan kosakata bahasa Marori siswa menunjukkan hasil yang maksimal. Sebanyak 18 siswa menyebutkan/meretrif 11 kata nama benda/tumbuhan berberdasarkan makna kata bahasa Marori dan berdasarkan skemata siswa dengan presentasi $100 \%$ hasil yang sangat maksimal.

Penelitian pengenalan kosakata bahasa Marori yang dilaksanakan di SD Impres Wasur pada siswa kelas V. Judul dalam penelitian ini adalah Pengenalan Bahasa Daerah Marori Menggunakan Teknik Retrival Jaringan Semantik. Dua topik yang digunakan dalam penelitian ini yaitu pohon sagu dan proses pengelolaanya, dan pengenalan kosakata bahasa yang berkaitan dengan marga. Hasil pembelajaran berbeda-beda. Dimana ketika kosakata yang diperkenalkan pada pertemuan awal terkait topi sagu dan proses pengelolaan siswa kesulitan dalam meretrif kosakata yang dikenalkan dan sulit mengembangkan peta semantik

Berdasarkan hasil penelitian bahwa kesulitan siswa dalam meretrif adalah karena dalam kehidupan keseharian siswa tidak lagi mendengar kosakata bahasa daerah yang dituturkan dalam kehidupan siswa. Sehingga untuk mengenalkan kosakata terkait pohon sagu dan proses pengelolaan sagu siswa harus belajar secara intens walau pun tidak maksimal. Sedangkan hasil belajar dengan topik pengenalan marga, siswa lebih kreaktif dan hasil pembelajaran sangat maksimal. Berdasarkan hasil penelitian, siswa lebih mengetahui dan mengenal kosakata berkaiatan dengan nama marga sehingga siswa mampu meretrif dan mengembangkan peta semantik dengan 
maksimal. Dengan demikian, guru dapat menggu-nakan teknik retrival jaringan semantik dalam kegiatan belajar mengajar kosakata bahasa Marori.

\section{Pembahasan}

Proses pembelajaran berdasarkan rancangan penelitian yaitu pengenalan kosakata bahasa daerah suku marori (Marind-Merauke) dalam pembelajaran bahasa Indonesia dengan menggunakan teknik retrival jaringan semantik menunjukkan bahwa awal pertemuan siswa sangat kesulitan dalam meretrief kosakata bahasa Marori, karena proses transformasi bahasa daerah hampir jarang dituturkan dalam kehidupan keseharian masyarakat di Wasur kampung. Bahkan, bahasa Marori hampir saja punah. Hal ini terutama disebabkan oleh faktor sosio-historis-budaya eksternal yang telah mempengaruhi dan membentuk ekologi saat ini di Merauke (Hisa, 2017). Salah satu tumbuhan yang menjadi bahan pembelajaran adalah pohon sagu dan pengenalan marga suku asli. Ketika siswa diminta untuk mengucapkan atau meretrif kosakata pohon sagu tampak kesulitan, sehingga peneliti membantu siswa dengan menayangkan bahan dalam bentuk PowerPoint yang telah disiapkan kemudian slide ditutup dan peneliti meminta siswa mencoba menjawab atau mendefenisikan kata-kata dalam bentuk peta semantik. Faktor-faktor dari kesulitan siswa dalam meretrif kosakata bahasa daerah adalah faktor lingkungan dan keluarga. Hal tersebut sesuai dengan pernyataan dari Patana dan Sumarsono yang menyebutkan bahwa penguasaan kosakata anak dapat dipengaruhi oleh berbagai faktor baik lingkungan keluarga, sosial, dan lingkungan bermain anak (Sumarsono, 2002).

Sementara menurut Biemiller (Andi, 2017) pengajaran atau pemerolehan kosakata adalah hal yang berguna dalam menunjang keberhasilan suatu berbahasa. Selanjutnya menurut Sudirman \& Ridha (Andi, 2017). Pengajaran kosakata bahasa tertentu memerlukan metode yang tepat guna memberikan manfaat belajar kepada pembelajar. Dari beberapa pernyataan di atas, dapat disimpulkan bahwa pembelajaran kosata dalam pembelajaran bahasa sangat penting guna peningkatan penguasaan keterampilan bahasa. Artinya semakin banyak kosakata bahasa yang dipelajari dan dipahami maka semakin terampilan keterampilan bahasa seseorang (Pradana, 2018).

Kajian untuk mempertahankan bahasa daerah saat ini dilakukukan sebagai bentuk mempertahankan bahasa daerah sebagai indentitas daerah. Irawan (Gereda, 2017) mengemukakan bahwa upaya-upaya pemertahanan dan pemulihan bahasa daerah, antara lain: (1) pemupukan terhadap loyalitas bahasa dan kebanggaan berbahasa, (2) menempatkan bahasa daerah standar dialekdiaelek lokal dalam posisi sejajar sehingga keduanya dapat hidup berdampingan sesuai dengan fungsi masing-masing, (3) mendorong 
penggunaan bahasa daerah pada berbagai ranah, (4) perlu kebijakan yang berpihak kepada penerbitan media berbahasa daerah, yang mencakup buku bahasa daerah, buku cerita, dan media belajar, (5) mendorong pengasuan anak dengan bahasa daerah, (6) meningkatkan kualitas dan kuantitas pengajaran bahasa daerah, dan (7) menghidupkan tradisi lisan dan tulisan dalam bahasa daerah. Salah satu upaya pemertahanan bahasa-bahasa lokal di Indonesia yaitu dengan cara pembelajaran bahasa daerah sehingga potensi yang dimiliki oleh setiap daerah tetap dijaga. Salah satu dukungan yurudis formal tentang pemertahanan bahasa yaitu Pasal 36 UUD 1945.

Menurut Corder, (1981) efektivitas pembelajaran bahasa akan berjalan lebih baik seiring dengan proses alamiah pemerolehan bahasa seseorang. Ghazali, (2013) lebih lanjut mengarisbawahi bahwa mendorong kemajuan belajar seseorang lebih baik daripada menghambatnya. Hal tersebut dilakukan apabila sesorang memiliki pengetahuan yang cukup mendalam terhadap proses pemerolehan bahasa kedua. Untuk membelajarkan bahasa kedua atau bahasa target dalam pembelajar bahasa guru memiliki posisi sentral. Dalam pengajaran bahasa target guru memiliki peranan penting dalam mempertimbangkan bahan ajar yang digunakan dalam pembelajaran bahasa dan budaya, serta karakteristik siswa/pihak yang menerima pembelajaran (Ghazali, 2013).

Dawud (Dawud, 2008), menyatakan bahwa di dalam proses pembelajaran kosakata kata-kata diorganisasiskan dan digunakan dalam jaringan asosiatif. Setiap jaringan membentuk makna bahasa tertentu. Lebih lanjut ditegaskan bahwa hubungan asosiasi kata-kata sangat penting bukan hanya untuk belajar bermakna suatu kata, melainkan juga untuk mengembangkan kemamuan memahami, mengorganisasi, dan menggunakan kata secara tepat. Pengetahuan asosiasi kosakata tersebut sangat penting peranannya untuk mengembangkan kompetensi bahasa yang diperoleh oleh penutur asli.

Menurut Krashen (Ghazali, 2013), dalam proses pembelajaran bahasa kedua di kelas ada beberapa ciri-ciri pengajaran bahasa yang perlu dipenuhi yaitu: (1) dapat dipahami oleh siswa, (2) menarik bagi siswa, (3) bertaut dengan minat siswa, dan (4) tidak harus disajikan dengan memperhatikan urutan gramatikal, dan input tidak harus disajikan dengan takaran yang tidak berlebian. Kemudian, Ghazali, (2013) menyatakan bahwa pembelajaran bahasa yang terjadi di dalam kelas dapat mendorong proses pemerolehan bahasa, asalkan pembelajaran menyediakan input yang dapat dipahami maknanya oleh pembelajar. Dan lebih penting lagi pembelajar dapat memberikan kesempatan kepada pelajar dalam mempelajari bahasa target secara fungsional dan dalam interaksi komunikatif (Hermansyah, Harsiwi, Purwanty, \& Tembang, 2018).

Aspek-aspek yang mendukung proses pemerolehan bahasa dipengaruhi aspek kematangan biologis, kognitif, dan sosial. Slobin pernah menemukan bahwa pemerolehan bahasa 
dibangun sejak dini, dan kemampuan bahasa itu dikembangkan seiring perkembangan fisik anak dan berdasarkan pengalaman interaksi di dalam kehidupan anak (Dawud, 2008). Pembelajaran bahasa pertama di dalam proses pembelajaran sebagai bahasa antara dapat dilaksanakan sebagaimana dikatakan Selinker (dalam Dawud, 2008) bahwa ada lima macam gejala dalam bahasa antara yaitu (1) trasfer bahasa, yaitu unsur, kaidah, dan subsistem kaidah bahasa yang diperformasikan, (2) transfer latihan, yaitu unsur, kaidah, dan sistem bahasa diperoleh dari proses pengajaran, (3) strategi belajar bahasa kedua, yaitu, unsur,kaidah dan susbsistem bahasa diperoleh dengan pendekatan tertentu terhadap bahan pengajaran, (4) strategi komunikasi dnegan bahasa sasaran, yaitu bahasa yang diperoleh dengan mengadakan pendekatan belajar bahasa untuk berkomunikasi dengan penutur asli, dan (5) overgenerasilisasi, yaitu pelajar bahasa melakukan generalisasi berlebihan terhadap kaidah dan makna bahasa sasaran.

Model penyimpanan kata dan retrival kata merupakan proses mental yang terjadi pada manusia. Kata-kata yang didengar atau dibaca akan diingat selalu dan sewaktu-waktu akan diretrief kembali ketika ada stimulus yang masuk dalam otak manusia. Untuk menjelaskan bagaimana proses mental itu terjadi pada manusia menurut para psikolinguis mempunyai beberapa model teoretis terkait dengan penyimpanan kata dan retrival kata yaitu kata- kata yang tersimpan dalam otak manusia tidak hanya berasal dari proses membaca atau pun proses mendengar saja, melaikan dari proses audiovisual. Artinya apa yang dilihat semua akan disimpan dalam otak baik itu memori jangka panjang maupun memori jangka pendek (Nggaruaka, 2017). Dardjowidjojo menyatakan bahwa kata-kata tertentu akan mudah diretrif kembali apabila kata itu sering dipakai dalam proses komunikasi (Dardjowidjojo, 2010:169). Ormrod (2008:275) sebelumnya mengatakan retrifal kata merupakan kata proses penemuan informasi yang sebelumnya disimpan di dalam memori. Karpicke (2012:162) pula menyebutkan teknik retrival tidak hanya menjadi salah teknik untuk membantu memanggil kata-kata yang pernah didengar atau pelajari, tetapi lebih dari itu teknik retrival juga digunakan sebagai salah satu cara untuk menilai keberhasilan pembelajaran siswa setelah mempelajari materi ajar.

\section{KESIMPULAN}

Penelitian yang dilaksanakan di SD Negeri Wasur 1 merupakan salah satu penelitian kualitatif dengan jenis studi kasus pada siswa SD Negeri Wasur 1. Permasalahan yang mendasari proses penelitian yaitu: persoalan pengenalan koakata bahasa daerah Marori yang perlu dipertahankan serta menumbuhkemangkan rasa cinta siswa terhadap peroses pemerolehan bahasa Ibu. Untuk mempertahankan bahasa ibu sebagai salah satu aset budaya perlu pertisipasi semua pihak dalam rangkah pemertahanan bahasa. Upaya-upaya yang dilakukan adalah proses 
pembelajaran atau pun pengenalan kosakata bahasa sejak dini dan dimulai dari sekolah. Bahasa daerah merupakan salah satu sarana yang dapat dipakai untuk membelajarkan materimateri ajar di sekolah dengan perpaduan bahasa baik itu bahasa Indonesia, bahasa daerah atapun bahasa Inggris.

Hasil yang dicapai dalam penelitian ini menjadi acuan bahwa untuk membelajarkan materi-materi ajar perluy tahapan atau proses. Dengan adanya proses pembelajaran membentuk skemata siswa, sehingga ketika materi atau ada pertanyaan tertentu siswa mampu menyawab. Teknik retrival kata dengan jaringan semantik adalah salah satu bentuk pembelajaran yang dapat diterapkan dalam pembelajaran di semua jenjang pendidikan.

Hasil perpertemuan menunjukkan ada perubahan-perubahan karena ada upaya yang dilakukan dan pelaksanaan pembelajaran pada pertemuan sangat memuaskan. Rata-rata siswa menyebutkan/meretrif 11 kata nama benda/tumbuhan berdasarkan makna kata bahasa Marori dan berdasarkan skemata siswa dengan presentasi $100 \%$ hasil yang sangat maksimal.

\section{UCAPAN TERIMAKASIH}

Penelitian ini dapat terlaksana atas dukungan dari Rektor Univeristas Musamus, Ketua Lembaga Penelitian dan Pengabdian Universitas Musamus, dan Kementerian Riset, Teknologi, dan Pendidikan Tinggi melalui Simlitabmas 2018 pendanaan 2019 (skema penelitian dosen pemula).

\section{DAFTAR PUSTAKA}

Andi, S. A. N. R. A. (2017). Psikologi Pendidikan. Membantu Siswa Tumbuh dan Berkembang. Edisi keenam.

PenerjemahanWahyu, Eva, Airin dan Puji. Jurnal Ilmiah Terapan, 5(2).

Corder, S. P. (1981). Error Analysis and Interlanguage. London: Oxford University Press.

Dawud. (2008). Pengajaran Pemerolah Bahasa. Bandung: Angkasa Bandung.

Gereda, A. (2017). Tema-Tema Sosiolinguistik. Yogyakarta: Lingkar Antar Nusa.

Ghazali, S. A. (2013). Pembelajaran Keterampilan Berbahasa Dengan pendekatan Komunikatif Interaktif. Bandung: PT. Refika Aditama.

Hermansyah, A. K., Harsiwi, N. E., Purwanty, R., \& Tembang, Y. (2018). Increasing Indonesian Language Learning Results Through Reviewing Technique of Observation Result Through The Rotating Trio Exchange Method on Grade VI Students of Elementary School. 226(Icss), 1439-1443. https://doi.org/10.2991/icss18.2018 .303

Hisa, L. (2017). Dokumentasi EtnobotaniLinguistik Tumbuhan Sagu: Laporan Awal dari Etnis Marori di Taman Nasional Wasur Merauke. Jurnal Linguistik Indonesia, 32(2), 187-200.

Hyerle,N.D, Alper, L. 2012. Peta Pemikiran (Thinking Maps). Terjemahan Ati Cahayani 2012. Jakarta Barat: PT Indeks.

Mansoben, J. (1994). Sistem Politik Tradisional Irian Jaya, Indonesia. Indonesia: Studi Perndingan, LIPI RUN Jakarta.

Miles B Huberman, M. (1986). Qualitative Data Analysis:A Sourcebook of New Methods. Baverly Hill: Seage Publications.

Nggaruaka, T. (2017). Peningkatan Kemampuan Menulis Teks Deskripsi Dengan Menggunaka Teknik Retrival Jaringan Semantik Siswa Kelas Vii Smp Negeri I Kabupaten Merauke Provinsi

Рариа. Universitas Negeri malang.

Pradana, A. B. A. (2018). ENGLISH

LEARNING BASED ON MULTIPLE INTELLIGENCE IN TYPE OF LINGUISTIC INTELLIGENCE. 
DIDAKTIKA TAUHIDI: JURNAL PENDIDIKAN GURU SEKOLAH DASAR, 5(1), 41.

https://doi.org/10.30997/dt.v5i1.1110

Robert C Bogdan, S. K. B. (1990). Qualitative Research for Education:An Introduction Theory And Methods. London: Allyn and Bacon, Inc.

Soedjito. (1992). Kosakata Bahasa Indonesia. Jakarta: Gramedia.

Sugiono. (2016). Metode Penelitian Kuantitatif, Kualitatif, dan R\&D. Bandung: Penerbit Alfabet.

Sumarsono, P. (2002). Sosiolinguistik.
Yogyakarta: Sabda.

Tarigan, H. G. (1994). Pengajaran Pragmatik. Bandung: Penerbit Angkasa.

Trudell, D. B. B. (2008). Mother Tongue

Matters; Local Language as a Key to Effective Learning. Paris: Published by the United Nations Educational, Scientific and Cultural Organization.

Widyawati J. Wiwik, 2017. Mind Mapping Untuk Memperkaya Kosakata Bahasa Inggris Peserta Didik. BAHTERA: Jurnal Pendidikan Bahasa Dan Sastra, Volume 16 Nomor 1 Januari 2017. 